\title{
GAMBARAN STATUS KARIES DAN POLA PEMELIHARAAN KESEHATAN GIGI DAN MULUT PADA MAHASISWA ASAL TERNATE DI MANADO
}

\author{
${ }^{1}$ Radiah \\ ${ }^{2}$ Christy Mintjelungan \\ ${ }^{3} \mathrm{Ni}$ Wayan Mariati
}

\author{
${ }^{1}$ Kandidat Skripsi Program Studi Kedokteran Gigi Fakultas Kedokteran \\ Universitas Sam Ratulangi Manado \\ ${ }^{2}$ Bagian Ilmu Kesehatan Masyarakat Program Studi Kedokteran Gigi \\ Universitas Sam Ratulangi Manado \\ ${ }^{3}$ Bagian Ilmu Prostodonsia Program Studi Kedokteran Gigi Fakultas Kedokteran \\ Universitas Sam Ratulangi Manado \\ Email: radiah_03@yahoo.co.id
}

\begin{abstract}
Caries status is a condition that describes a person's caries experience index is calculated by DMF-T (Decayed missing filling theeth). Cariogenic food eating habits is the habit of a person consumes food that can cause caries, measured using questionnaires. Dental caries is one of the teeth and mouth disease most commonly found in the community. Factors that may affect the severity of caries experience caries among other things, the use of fluoride, the number of bacteria, saliva, age, sex, socio-economic and smoking. This research is a descriptive study with cross-sectional observational study. The populations student from Ternate city in Manado city is many 93 people. Based on the research status of caries, DMF-T index average is 3.1, and based on WHO criteria middle category. The results also showed patterns of oral health care are high category cariogenic foods and low category of non cariogenicc foods, sometimes brushing your teeth after eating as much in middle category and low categegory of students check their teeth to the dentist.
\end{abstract}

Keywords: status of caries, oral health care.

\begin{abstract}
Abstrak: Status karies adalah suatu kondisi yang menggambarkan pengalaman karies seseorang dihitung dengan indeks DMF-T (Deceyed missing filling theeth). Pola pemeliharaan kesehatan gigi dan mulut merupakan tindakan untuk memelihara kesehatan gigi dan mulut agar terhindar dari penyakit gigi dan mulut. Karies gigi merupakan salah satu penyakit gigi dan mulut yang paling sering dijumpai di masyarakat. Faktor-faktor yang dapat memengaruhi keparahan karies antara lain pengalaman karies, penggunaan fluor, jumlah bakteri, saliva, umur, jenis kelamin sosial ekonomi dan merokok. Penelitian ini merupakan penelitian deskriptif observasional dengan pendekatan cross sectional study. Populasi yang diteliti yaitu mahasiswa asal kota Ternate di kota Manado, berdasarkan survei awal berjumlah 93 orang. Berdasarkan hasil penelitian status karies, indeks DMF-T rata-rata yaitu 3,1 dan berdasarkan kriteria WHO berada pada kategori sedang. Hasil penelitian juga menunjukkan pola pemeliharaan kesehatan gigi dan mulut responden yang terdiri dari kebiasaan mengonsumsi makanan kariogenik berada pada kategori tinggi dan non kariogenik pada kategori rendah, menggosok gigi setelah makan berada pada kategori sedang dan mahasiswa yang pernah ke dokter gigi dan frekuensi kunjungan ke dokter gigi berada pada kategori rendah. Hasil penelitian kebersihan rongga mulut dengan menggunakan Oral Hygiene Index Simplified (OHI-S) pada gigi berjejal kedua rahang menunjukkan bahwa sebagian besar 66,67\% subjek penelitian memiliki kebersihan mulut baik
\end{abstract}


46 Jurnal e-GiGi (eG), Volume 1, Nomor 1, Maret 2013, hlm. 45-51

dan hasil penelitian status gingiva dengan menggunakan indeks gingiva pada gigi berjejal kedua rahang sebagian besar 65,22\% subjek penelitian memiliki status gingiva inflamasi ringan.

Kata kunci: status karies, pemeliharaan kesehatan gigi dan mulut.

Kesehatan merupakan faktor penting dalam kehidupan manusia. Kesehatan gigi dan mulut merupakan bagian dari kesehatan secara umum yang perlu diperhatikan oleh masyarakat. Oleh karena itu kesehatan gigi dan mulut pun harus sangat diperhatikan. Masalah kesehatan gigi dan mulut yang sering terjadi yaitu karies. Karies merupakan suatu penyakit pada jaringan keras gigi, yaitu email, dentin dan sementum yang disebabkan aktivitas jasad renik yang ada dalam suatu karbohidrat yang diragikan. Proses terjadinya karies dimulai dengan adanya plak di permukaan gigi. ${ }^{1}$

Berdasarkan Riset Kesehatan Dasar (Riskesdas) tahun 2007, kelompok umur 1024 tahun lebih banyak menderita karies yakni 66,8-69,5\%. Keadaan ini menunjukkan karies gigi banyak terjadi pada golongan usia produktif. Hal yang demikian dapat dilihat dari prevalensi rata-rata penduduk Indonesia bermasalah gigi dan mulut sebesar 23,4\%. Prevalensi rata-rata karies yang diukur dengan indeks DMF-T sebesar 4,85 yang berarti rata-rata penduduk Indonesia telah mengalami kerusakan gigi sebanyak 5 gigi per orang. Selain itu, dilihat dari jumlah penduduk Indonesia yang tidak menyikat gigi yaitu sebanyak 22,8\% dan dari $77,2 \%$ yang menyikat gigi tersebut cuma $8,1 \%$ yang menyikat gigi tepat pada waktunya. Fakta yang terjadi $72,1 \%$ penduduk Indonesia memiliki masalah karies dan $46,5 \%$ diantaranya tidak melakukan perawatan terhadap karies yang dideritanya. Kesadaran orang dewasa untuk datang ke dokter gigi kurang dari 7\% dan pada anakanak hanya sekitar 4\% kunjungan ke dokter gigi. selain itu, kebiasaan masyarakat suka mengkonsumsi makanan kariogenik akan meningkatkan resiko terkena karies. ${ }^{2}$

Data dari Riskesdas tahun 2007 juga menunjukkan bahwa, Sulawesi Utara mempunyai prevalensi masalah gigi dan mulut yang mencapai 47,4\% dengan indeks DMF$\mathrm{T}$ mencapai 5,01 dan di provinsi Maluku
Utara mencapai 39,8\% dengan indeks DMF$\mathrm{T}$ 4,60. ${ }^{3}$ Data Dinas Kesehatan Sulawesi Utara tahun 2009, menunjukkan jumlah pengunjung puskesmas dengan karies berkisar 6407 orang atau sekitar $20 \%{ }^{4}$

Upaya kesehatan gigi perlu ditinjau dari aspek lingkungan, pengetahuan, pendidikan, kesadaran dan penanganan kesehatan gigi termasuk pencegahan dan perawatan. Namun, sebagian besar mahasiswa asal kota Ternate yang ada di kota Manado mengabaikan kondisi kesehatan gigi secara keseluruhan. Perawatan gigi dianggap tidak terlalu penting, padahal sangat besar manfaatnya dalam menunjang kesehatan dan penampilan. Selain itu rasa takut, perawatan yang memakan waktu lama dan biaya yang cukup tinggi memungkinkan terjadinya resiko karies pada mahasiswa asal kota Ternate. Menjaga kebersihan gigi dan mulut sangatlah penting, beberapa masalah mulut dan gigi terjadi karena kita kurang menjaga kebersihan gigi dan mulut. Kesadaran menjaga kebersihan mulut sangat perlu dan merupakan obat pencegah terjadinya karies.

Berdasarkan latar belakang diatas serta belum adanya penelitian yang dilakukan serta tidak adanya data statistik mengenai status karies dan pola pemeliharaan kesehatan gigi dan mulut pada mahasiswa asal kota Ternate di kota Manado maka peneliti tertarik untuk melakukan penelitian mengenai status karies dan pola pemeliharaan kesehatan gigi dan mulut pada mahasiswa asal kota Ternate di kota Manado.

\section{METODE PENELITIAN}

Penelitian ini merupakan penelitian deskriptif observasional dengan pendekatan cross sectional study (potong lintang). Penelitian ini dilaksanakan di kota Manado pada bulan Mei-Juni 2012. Populasi yang diteliti yaitu mahasiswa asal kota Ternate di kota Manado, berdasarkan survei awal berjumlah 93 orang. Kriteria inklusi Mahasiswa kota Ternate bersedia menjadi 
subjek penelitian, bersifat kooperatif selama pengambilan data, Terdaftar dan aktif sebagai mahasiswa disalah satu perguruan tinggi di Kota Manado. Mahasiswa yang tidak bersedia menjadi subjek dalam penelitian ini dan mahasiswa yang tidak hadir pada saat penilitian dimasukkan dalam kriteria eksklusi. Teknik pengambilan sampel yang digunakan ialah total sampling, yakni mengambil seluruh jumlah mahasiswa yang memenuhi kriteria inklusi. Variabel penelitian ini yaitu status karies dan pola pemeliharaan kesehatan gigi dan mulut.

Status karies adalah suatu kondisi yang menggambarkan pengalaman karies seseorang yang dihitung dengan menggunakan indeks DMF-T (Decayed missing filling theeth) menurut Klein $\mathrm{H}$, Palmer $\mathrm{CE}$ dan Knutson JW.

Indeks DMF-T ialah indeks yang digunakan pada gigi permanen untuk menunjukkan banyaknya gigi yang terkena karies. D (Decayed): Lubang pada gigi akibat dekalsifikasi jaringan email gigi yang terlihat keputih-putihan atau kecoklatan dengan ujung sonde terasa menyangkut pada kavitas. M (Missing) : Hilangnya gigi permanen karena telah tanggal atau dicabut, maupun karies gigi permanen yang diindikasikan untuk pencabutan, seperti jika mahkota gigi tidak ada atau hanya tinggal akar. F (Filling): Tambalan atau tumpatan pada gigi permanen baik secara tetap maupun berupa tambalan sementara.

Kategori DMF-T menurut WHO antara lain; sangat rendah $(0,8-1,1)$, rendah $(1,2-$ $2,6)$, sedang $(2,7-4,4)$, tinggi $(4,5-6,5)$, sangat tinggi $(>6,6)$.

Pola pemeliharaan kesehatan gigi dan mulut merupakan tindakan untuk memelihara kesehatan gigi dan mulut agar terhindar dari penyakit gigi dan mulut. Tindakan tersebut berupa mengurangi konsumsi makanan kariogenik, banyak mengonsumsi sayur dan buah, menggosok gigi sesudah makan dan kunjungan rutin kedokter gigi setiap 6 bulan sekali.

Kategori frekuensi mengonsumsi makanan kariogenik dan non kariogenik. Tinggi (setiap hari), sedang (4-6 hari seminggu), rendah (3-1 hari seminggu), sangat rendah (tidak pernah).

Kategori tindakan menggosok gigi atau berkumur setelah makan; Baik (ya), sedang (kadang-kadang), buruk (tidak pernah). Kategori kunjungan ke dokter gigi; Baik (ya), buruk (tidak pernah).

Instrument yang digunakan dalam penelitian yaitu formulir pemeriksaan indeks DMF-T dan kuesioner. Alat dan bahan yang digunakan yaitu Alat diagnostik, alkohol, betadine dan kapas.

Pengumpulan data dilakukan melalui Pertimbangan etik Permohonan ijin penelitian ini diperoleh dari paguyuban MAHKOTA (Mahasiswa Kota Ternate) dan para mahasiswa yang akan dijadikan subjek penelitian melalui informed consent.

Data primer diperoleh dari hasil pemeriksaan DMF-T (Decayed Missing Filling-Teeth) dan hasil dari kuesioner yang dibagikan oleh peneliti.

Data sekunder diperoleh dari profil paguyuban MAHKOTA (Mahasiswa Kota Ternate) yang meliputi data jumlah mahasiswa asal kota Ternate di Manado. Data yang diperoleh diolah dan dianalisis kemudian disajikan dalam bentuk tabel distribusi frekuensi.

\section{HASIL PENELITIAN}

Mahasiswa asal kota Ternate yang berada di kota Manado merupakan mahasiswa yang berdomisili di kota Ternate yang kemudian melanjutkan studi di perguruan-perguruan tinggi yang ada di kota Manado. Mahasiswa-mahasiswa ini diorganisir oleh sebuah organisasi yang disebut MAHKOTA (Mahasiswa Kota Ternate).

Jumlah mahasiswa asal kota Ternate saat ini mencapai 137 orang namun responden pada penelitian ini berjumlah 90 orang. Karakteristik responden menurut jenis kelamin menunjukkan bahwa mahasiswa lakilaki berjumlah 51 orang (56,7\%) dan mahasiswa perempuan berjumlah 39 orang (43,3\%).

Pemeriksaan status karies dilihat dari jumlah gigi yang berlubang, jumlah gigi yang hilang dan jumlah gigi yang ditambal. 
Kemudian hasil jumlah dari komponen DMF dibagi dengan jumah responden sehingga didapatkan rata-rata indeks DMFT.

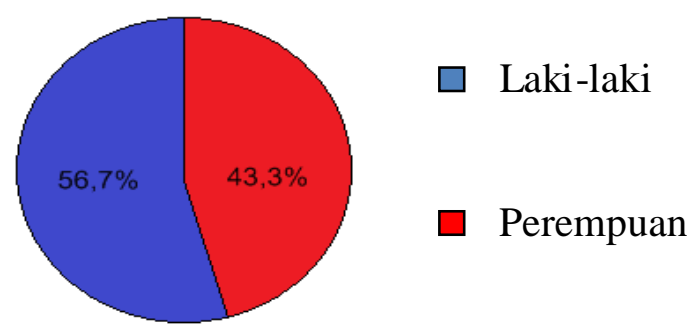

Gambar 1. Karakteristik responden berdasarkan jenis kelamin.

Tabel 1. Distribusi masing-masing komponen DMF-T dan indeks rata-rata DMF-T

\begin{tabular}{lcc}
\hline Komponen DMF & $\begin{array}{c}\text { Jumlah } \\
\text { (n) }\end{array}$ & $\begin{array}{c}\text { Presentase } \\
\text { (\%) }\end{array}$ \\
\hline D (Decayed) & 175 & 61,4 \\
M (Missing) & 76 & 26,7 \\
F (Filling) & 34 & 11,9 \\
Jumlah & $\mathbf{2 8 5}$ & $\mathbf{1 0 0}$ \\
\hline
\end{tabular}

Hasil pemeriksaan DMF-T pada mahasiswa asal kota Ternate di kota Manado yaitu indeks D (Decayed) berjumlah 175 (61,4\%), M (Missing) berjumlah 76, dan F (Filling) berjumlah 34. Hasil penelitian juga menunjukkan indeks DMF-T rata-rata untuk seluruh responden yaitu 3,1. Berdasarkan kriteria dari WHO, indeks ini berada pada kategori status karies sedang.

Tabel 2. Distribusi responden berdasarkan kategori status karies

\begin{tabular}{ccc}
\hline Status Karies & Jumlah (n) & $\begin{array}{c}\text { Presentase } \\
\mathbf{( \% )}\end{array}$ \\
\hline Sangat rendah & 17 & 18,9 \\
Rendah & 19 & 21,1 \\
Sedang & 38 & 42,2 \\
Tinggi & 14 & 15,6 \\
Sangat tinggi & 2 & 2,2 \\
Jumlah & $\mathbf{9 0}$ & $\mathbf{1 0 0}$ \\
\hline
\end{tabular}

berdasarkan kategori status karies dalam perhitungan DMF-T responden menurut kriteria WHO, kategori yang paling tinggi yaitu pada kategori status karies sedang yakni terdapat 38 responden (42,2\%).

Pola pemeliharaan kesehatan gigi dan mulut dapat dilihat dari jenis makanan yang dikonsumsi, frekuensi makan makanan yang bersifat kariogenik, menyikat gigi setelah makan dan kunjungan ke dokter gigi.

Tabel 3. Distribusi responden berdasarkan kategori mengonsumsi makanan kariogenik dan non kariogenik.

\begin{tabular}{lcccc}
\hline \multirow{2}{*}{ Kategori } & \multicolumn{2}{l}{$\begin{array}{l}\text { Makanan } \\
\text { Kariogenik }\end{array}$} & \multicolumn{2}{c}{$\begin{array}{l}\text { Non } \\
\text { Kariogenik }\end{array}$} \\
\cline { 2 - 5 } & $\mathrm{n}$ & $\%$ & $\mathrm{n}$ & $\%$ \\
\hline Tinggi & 41 & 45,6 & 0 & 0 \\
Sedang & 36 & 40,0 & 0 & 0 \\
Rendah & 13 & 14,4 & 90 & 100 \\
Sangat rendah & 0 & 0 & 0 & 0 \\
Jumlah & 90 & 100 & 90 & 100 \\
\hline
\end{tabular}

Berdasarkan tabel di atas, dapat dilihat bahwa jumlah responden yang mengonsumsi makanan kariogenik pada kategori tinggi terdapat 41 responden (45,6\%), kategori sedang terdapat 36 responden $(40,0 \%)$, kategori rendah terdapat 13 orang $(14,4 \%)$ dan sangat rendah tidak terdapat responden. Jumlah responden yang mengonsumi makan non kariogenik pada kategori tinggi tidak terdapat responden, pada kategori sedang juga tidak ada responden dan tidak ada responden juga pada kategori sangat rendah. Kategori rendah terdapat 90 responden (100\%).

Tabel 4. Distribusi responden berdasarkan kategori tindakan menggosok gigi atau berkumur setelah makan.

\begin{tabular}{lcc}
\hline Kategori & $\begin{array}{c}\text { Jumlah } \\
\text { (n) }\end{array}$ & $\begin{array}{c}\text { Presentase } \\
\text { (\%) }\end{array}$ \\
\hline Baik & 3 & 3,3 \\
Sedang & 87 & 96,7 \\
Buruk & 0 & 0 \\
Total & 90 & 100 \\
\hline
\end{tabular}

Dari tabel 5 dapat di ketahui bahwa tindakan menggosok gigi atau berkumur setelah makan yang terdapat pada kategori 
baik sebanyak 3 responden (3,3\%), yang terdapat pada kategori sedang sebanyak 87 responden $(96,7 \%)$ dan tidak ada responden pada kategori buruk.

Tabel 5. Distribusi responden berdasarkan kategori kunjungan ke dokter gigi

\begin{tabular}{lcc}
\hline Kategori & $\begin{array}{c}\text { Jumlah } \\
(\mathrm{n})\end{array}$ & $\begin{array}{c}\text { Presentase } \\
(\%)\end{array}$ \\
\hline Baik & 36 & 40 \\
Buruk & 54 & 60 \\
Total & $\mathbf{9 0}$ & $\mathbf{1 0 0}$ \\
\hline
\end{tabular}

Berdasarkan tabel diatas, dapat dilihat bahwa terdapat 36 responden (40\%) pada kategori baik dan pada kategori buruk sebanyak 54 responden (60\%).

\section{BAHASAN}

Hasil penelitian yang menggunakan indeks DMF-T pada mahasiswa asal kota Ternate di kota Manado menunjukkan indeks yang paling tinggi yaitu indeks D (Decayed) dengan jumlah 175 gigi (61,4\%). Banyaknya jumlah gigi yang mengalami karies mungkin karena usia yang semakin bertambah maka kemungkinan terjadinya karies semakin meningkat. Menurut penelitian dari Sihombing tentang karakteristik penderita karies gigi di RSUD Dr. Pirngadi Medan, usia $>14$ tahun mengakibatkan waktu paparan makanan yang mengandung gula dan bersifat kariogenik terhadap gigi semakin lama, apabila tidak didukung oleh kebersihan gigi dan mulut akan mudah mengalami demineralisasi sehingga karies dapat terbentuk. Penelitian tersebut juga menunjukkan proporsi terbesar karies gigi didapati pada pelajar atau mahasiswa yakni 42,1\%. ${ }^{5}$ Gigi molar merupakan gigi yang paling sering mengalami karies karena gigi ini paling sering digunakan untuk mengunyah makanan sehingga terjadi penumpukkan sisa-sisa makanan yang dapat menyebabkan karies. Letaknya di bagian belakang yang susah untuk dibersihkan sendiri dan memiliki banyak pit dan fisur sehingga plak dan bakteri mudah menumpuk pada gigi ini dan dapat menyebabkan karies. ${ }^{6}$
Peningkatan status karies sangat erat kaitannya dengan bertambahnya umur seseorang. Pengaruh umur terhadap status karies gigi disebabkan oleh beberapa hal yaitu berkurangnya produksi air ludah dan lebih lama terpapar makanan dan minuman manis dalam proses pengunyahan yang dapat menyebabkan kerusakan gigi semakin banyak dan semakin parah. Hal inilah yang mengindikasikan indeks decayed pada mahasiswa asal kota Ternate di kota Manado sangat tinggi yakni 175 gigi $(61,4 \%)$.

Dalam penelitian juga menunjukkan bahwa status karies dalam perhitungan DMF-T menurut kriteria WHO, paling tinggi berada pada kategori sedang yaitu terdapat 38 responden (42,2\%), sedangkan yang paling rendah terdapat pada kategori sangat tinggi yaitu 2 responden (2,2\%). Pendapat ini diperkuat dengan penelitian Hawkins dan kawan-kawan yang mengatakan bahwa pendidikan kesehatan yang diberikan harus diikuti dengan pelatihan sehingga untuk meningkatkan kesadaran tersebut dibutuhkan pendidikan kesehatan yang mencakup adanya proses komunikasi, motivasi dan instruksi yang memadai. ${ }^{7}$ Berdasarkan hal tersebut, penulis berpendapat bahwa kategori sedang pada mahasiswa asal kota Ternate di kota Manado, mungkin saja dikarenakan mahasiswa kurang memiliki kesadaran untuk menerapkan kebiasaan yang baik dalam memelihara kebersihan gigi dan mulut sehari-hari.

Mahasiswa kota Ternate yang melanjutkan studi di perguruan tinggi yang ada di kota Manado memungkinkan terjadinya perubahan gaya hidup karena perpindahan dari kota kecil ke kota besar yang dapat menyebabkan resiko terjadinya karies, selain itu jauh dari orang tua menyebabkan kesehatan diri sendiri kurang diperhatikan karena telah disibukkan dengan kegiatan perkuliahan dan kegiatan kemahasiswaan lainnya, sehingga dapat terjadinya resiko karies.

Secara umum pola pemeliharaan kesehatan gigi dan mulut mahasiswa asal kota Ternate di kota Manado dari hasil penelitian yang dilakukan dapat dilihat bahwa sebagian besar mahasiswa setiap hari 
mengonsumsi makanan kariogenik. Data penelitian menunjukkan bahwa jumlah responden yang mengonsumsi makanan kariogenik setiap hari terdapat 41 responden (45,6\%) dan terdapat pada kategori tinggi. Pada saat ini makanan kariogenik memiliki berbagai macam bentuk, rasa dan warna sehingga mahasiswa kota Ternate memiliki ketertarikan untuk mengonsumsi makanan tersebut. Penelitian ini didukung oleh penelitian Barus yang bahwa adanya hubungan yang signifikan antara frekuensi mengonsumsi makanan kariogenik dengan timbulnya karies gigi. Hasil penelitian oleh Siagian di Medan tahun 2008 juga menunjukkan bahwa masyarakat yang sering mengkonsumsi makanan kariogenik ternyata paling banyak menderita karies. $^{7}$

Makanan yang manis dan lengket akan melekat pada permukaan gigi dan terselip di dalam celah-celah gigi sehingga merupakan makanan yang paling merugikan kesehatan gigi. ${ }^{6}$ Kerugian ini terjadi akibat proses metabolisme oleh bakteri yang berlangsung lama sehingga menurunkan $\mathrm{pH}$ mulut untuk waktu lama. Sukrosa yang terkandung dalam makanan kariogenik ini merupakan substrat bagi mikroorganisme plak yang akan menghasilkan asam dan menyebabkan demineralisasi jaringan keras gigi. ${ }^{7}$ Semakin sering responden mengkonsumsi kariogenik ini, maka akan semakin lama proses demineralisasi tanpa diikuti dengan proses remineralisasi secara sempurna sehingga terbentuk lesi yang lama-kelamaan akan terbentuk karies.

Dari data penelitian juga menunjukkan semua responden memilih frekuensi 1-3 hari dalam seminggu yakni berada pada kategori rendah. Mengonsumsi buah-buahan sehabis makan sama dengan pembersihan gigi secara alami, karena hal ini dapat mengurangi terjadinya karies gigi. ${ }^{7} \mathrm{Di}$ mana makanan yang perlu pengunyahan yang baik akan meningkatkan kebersihan mulut. Mengonsumsi buah dan sayur yang berserat dan sedikit karbohidrat sebagai penghambat terjadinya karies. Buah-buahan yang berserat dan berair akan bersifat membersihkan dan karena harus dikunyah maka dapat merangsang sekresi saliva.
Hasil penelitian diketahui bahwa tindakan menggosok gigi atau berkumur setelah makan paling banyak pada kategori sedang yaitu sebanyak 87 orang $(96,7 \%)$. Mahasiswa lebih banyak menjawab kadangkadang menggosok gigi atau berkumur setelah makan mungkin disebabkan rasa kurang peduli terhadap kesehatan gigi dan mulut mereka. Makanan yang bersifat kariogenik bila dikonsumsi lebih dari 5 menit di dalam mulut akan lebih beresiko menyebabkan karies karena semakin lama makanan ini menempel pada gigi akan menghasilkan asam yang lebih banyak pula yang jika dibiarkan akan menimbulkan plak yang menyebabkan karies gigi. ${ }^{8}$ Menurut Machfoedz kebiasaan makan makanan yang bersifat kariogenik sebenarnya tidak akan menjadi masalah bila sesudah mengonsumsi makanan tersebut segera dibersihkan paling tidak dengan berkumur-kumur. ${ }^{6}$ Penelitian ini di dukung oleh penelitian Barus yang menyatakan bahwa ada hubungan yang bermakna antara tindakan pemeliharaan kesehatan gigi dan mulut dengan karies gigi. ${ }^{7}$ Menyikat gigi atau berkumur setelah makan secara teratur merupakan faktor yang sangat penting untuk mempertahankan kebersihan mulut dan gigi agar terhidar dari karies.

Selain itu, hasil penelitian menunjukkan kurangnya kesadaaran mahasiswa untuk memeriksakan giginya ke dokter gigi. Berdasarkan hasil penelitian frekuensi kunjungan kedokter gigi dalam setahun hanya $40 \%$ mahasiswa yang memeriksakan giginya ke dokter gigi, sedangkan $60 \%$ mahasiswa tidak pernah melakukan kunjungan ke dokter gigi. Sering kita jumpai seseorang yang datang berobat ke dokter gigi dalam keadaan terlambat, sehingga dapat diindikasikan bahwa tingkat kesadaran mahasiswa kota Ternate pada umumnya untuk berobat sedini mungkin masih belum dapat dilaksanakan. Untuk meningkatkan kesadaran mahasiswa tentang pentingnya perawatan kesehatan gigi dan mulut, dokter gigi sebaiknya memberikan penjelasan yang mudah dimengerti dan dipahami. Beberapa faktor yang dapat menghambat mahasiswa untuk melakukan perawatan kesehatan gigi dan mulut yakni takut akan rasa sakit, waktu 
perawatan yang lama, rasa tidak nyaman dan biaya yang cukup tinggi.

Dari teori dan dukungan penelitian di atas penulis berasumsi bahwa status karies dengan indeks DMF-T 3,1 yang merupakan kategori sedang menurut WHO, artinya ratarata setiap mahasiswa kota Ternate telah mengalami kerusakan gigi sebanyak 3 gigi per orang mungkin dipengaruhi oleh tinggi kebiasaan mahasiswa mengonsumsi makanan yang bersifat kariogenik, jarang mengonsumsi buah-buahan yang berserat dan mengandung banyak air. Selain itu, dimungkinkan juga kurangnya kesadaran memeriksakan kesehatan gigi dan mulutnya ke dokter gigi merupakan penyebab terjadinya karies pada mahasiswa asal kota Ternate di kota Manado.

\section{SIMPULAN DAN SARAN}

Berdasarkan hasil penelitian, maka dapat disimpulkan bahwa, Status karies berdasarkan indeks DMF-T rata-rata untuk 90 orang responden yaitu 3,1, yang artinya rata-rata responden memiliki 3 gigi karies. Berdasarkan kriteria dari WHO, indeks ini berada pada kategori status karies sedang dan pola pemeliharaan kesehatan gigi dan mulut responden yang terdiri dari kebiasaan mengonsumsi makanan kariogenik berada pada kategori tinggi dan non kariogenik pada kategori rendah, menggosok gigi setelah makan berada pada kategori sedang dan mahasiswa yang pernah ke dokter gigi dan frekuensi kunjungan ke dokter gigi berada pada kategori rendah. Saran Bagi mahasiswa kota Ternate diharapkan dapat meningkatkan kesadaran akan kesehatan gigi dan mulut sebagai suatu tindakan preventif terhadap terjadinya karies dengan memeriksakan gigi ke dokter gigi setiap 6 bulan sekali.

\section{UCAPAN TERIMA KASIH}

Penulis mengucapkan terima kasih kepada drg. drg. Vonny N. S. Wowor MKes (Dosen penguji I) dan, P.S Anindita, Sp Orto (Dosen penguji II) atas masukan yang telah diberikan kepada penulis. Penulis juga mengucapkan terima kasih kepada semua pihak yang telah membantu penulis dalam menemukan ide dalam penulisan karya tulis ini.

\section{DAFTAR PUSTAKA}

1. Jose O. Cortes G, Carlo E, Solis M, Juan P, Jorge A et al. Dental caries' experience, prevalence and severity in Mexican adolescents and young adults. Mexico: Sauld Publica; 2009. p.83-84.

2. Pintauki S. Hamada T. Menuju gigi dan mulut sehat: pencegahan dan pemeliharaan. Medan: USU Press; 2008. h. 4-24. Available from: URL: http://repository.usu.ac.id/

3. Dinas Kesehatan Provinsi Sulawesi Utara. Rekapitulasi laporan bulanan data kesakitan (LB-1) Kab/Kota se-provinsi Sulut. Sulawesi Utara, 2008.

4. Riset Kesehatan Dasar. Laporan kesehatan gigi dan mulut; 2007.

5. Sihombing J. Karakteristik penderita karies yang berobat di RSU Dr. Pringadi Medan. Medan: USU Press; 2008. h.1-12. Available from URL: http://repository.usu.ac.id/

6. M Paula, Petersen PE. Diet, nutrition and the prevention of dental diseases. Denmark: Public Health Nutrition. 2004.

7. Barus D. Hubungan kebiasaan makan dan pemeliharaan kesehatan gigi dengan karies gigi pada anak SD 060935 di jalan pintu air II simpang gudang kota medan tahun 2008. Medan. USU Press; 2009.h.57-61. Available from URL: http://repository.usu.ac.id/

8. Moreira RS. Epidemiology of dental caries in the world. Brazil: In Tech; 2008.p.149-150 